\title{
Títulos de crédito em branco e incompletos: análise dos requisitos essenciais de formação e dos efeitos jurídicos do pacto de preenchimento
}

\author{
In blank and incomplete negotiable instruments: an analysis of the essential \\ requirements of its formation and the legal effects of the filling agreement
}

\author{
ANDRÉ FERnANDES ESTEVEZ ${ }^{\mathrm{a}}$
}

\begin{abstract}
RESUMO
Retoma-se a análise dos títulos de crédito em branco e incompletos através de perspectiva crítica, com a finalidade de determinar os requisitos mínimos para a sua circulação, em especial nos títulos de crédito atípicos e nos documentos cambiários clássicos, como a letra de câmbio, a nota promissória, a duplicata e o cheque. Faz-se a análise do pacto de preenchimento e de suas consequências jurídicas, partindo de comparações legislativas. Em análises da evolução histórica da matéria, verifica-se pontuais distorções jurisprudenciais. Na atualidade, nota-se uma tensão interpretativa, dimensionada pelo dissenso sobre o grau de formalidade exigível à aplicação do Direito Cambiário.
\end{abstract}

Palavras-chave: Direito Cambiário. Título de crédito em branco, incompleto. Pacto de preenchimento. Requisitos essenciais.

\begin{abstract}
This research resumes the analysis of the in blank and the incomplete negotiable instruments through critical perspective, with the aim to determinate the minimal requirements to its circulations, especially in atypical negotiable instruments and its classical forms, as example of the bill of exchange, the promissory note and the cheque. Also, it makes the analysis of the filling agreement and its legal consequences, starting in legislative comparisons. In review of the historical evolution of the subject, is seen specific distortions in jurisprudence. Nowadays, is possible to observe an interpretative strain, dimensioned by a dissent about the applied degree of formality required the application of negotiable instruments Law.

Keywords: Negotiable instruments Law. "In blank" and incomplete negotiable instruments. Filling agreement. Essential requirements.
\end{abstract}

\section{INTRODUÇÃO}

Os títulos de crédito foram criados com a menção de ser a maior contribuição do Direito Comercial à economia moderna ${ }^{1}$, calcado nos mais diversos ordenamentos com traços fundamentais comuns, derivados das "constantes e universais exigências econômicas"'.

Os títulos de crédito não surgiram para circular riquezas, mas para tornar possível o transporte de dinheiro entre cidades, preocupação relevante para o final da Idade Média no norte da Itália. Atualmente, possibilita a circulação do crédito ${ }^{3}$.
Construiu-se sua teoria geral sobre a letra de câmbio ${ }^{4}$. Aos demais títulos restou uma segmentação autônoma pelas particularidades envolvidas, como ocorre, exemplificativamente, entre a nota promissória e a letra de câmbio, que apresentam pontos de distinção e de similitude. Assim, cada espécie cambiária "guarda uma autonomia própria que advém das alterações dos

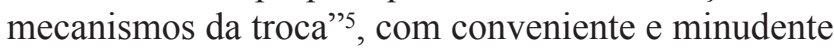
regulação legislativa individual ${ }^{6}$.

A teoria geral dos títulos de crédito apresentase movediça e isso ocorre particularmente por duas razões: (a) ao longo do tempo varia os rol de títulos de crédito que formam a teoria, cada um com as suas 
especificidades; (b) os títulos de crédito atípicos vem marcados pela teoria geral, mas também a alteram em seus limites ${ }^{7}$. De toda forma, as teorias partem de um pressuposto comum, que é a duplicação da relação fundamental $^{8} \mathrm{em}$ documento cambiário para poder gerar a autonomia do mesmo?.

Com o tempo, a matéria passou por novas dificuldades que já eram mencionadas por Nelson Abrão em 11/01/1976, em publicação feita em O Estado de São Paulo, em que assinalou que a França já vinha se convertendo ao uso da informática ${ }^{10}$. Assim, em 1979 já afirmava Newton de Lucca que não seria desarrazoado que num futuro não muito distante, com as necessidades econômicas e as "avassaladoras conquistas no campo da eletrônica, a ciência jurídica - embora a mais refratária às transformações do mundo moderno - poderá passar por profundas reformulações em seus mais diferentes ramos" ${ }^{\prime 1}$. Exemplos mais atuais das referidas controvérsias encontram-se, exemplificativamente, em artigo de Luís Felipe Spinelli ${ }^{12}$.

Desde a sua origem, os títulos de crédito são considerados instrumentos extremamente formalistas em prol da simplicidade na circulação do crédito. Limitou-se a autonomia privada para que se soubesse, com maior segurança, quais seriam os efeitos jurídicos decorrentes de certa relação ${ }^{13}$.

Como fruto do caráter formalista, as leis de regência da matéria exigem o preenchimento de determinados requisitos previstos em lei para que se extraiam os efeitos cambiais. No entanto, os títulos podem ser postos em circulação sem que tenham sido integralmente preenchidos, constituindo motivo para certa insegurança, contrária aos próprios fins do instituto, e que tem provocado severas discussões na doutrina ${ }^{14}$.

O objetivo com os capítulos vindouros está em trazer as delimitações necessárias para compreender os requisitos essenciais dos títulos de crédito em branco e incompletos, bem como os efeitos jurídicos daí decorrentes.

\section{FORMAÇÃO DO TÍTULO DE CRÉDITO}

Os diversos títulos de crédito, para que sejam considerados hábeis a gerar os seus efeitos cambiários, devem preencher inúmeros requisitos legais, como se observa exemplificativamente na letra de câmbio ${ }^{15}$, na nota promissória ${ }^{16}$, no cheque ${ }^{17}$ e na duplicata ${ }^{18}$. A inexistência de algum dos requisitos formais no momento do exercício da pretensão - ação ou protesto - implica na nulidade do título de crédito $^{19}$, embora se observe certa flexibilização de tais consequências nos Tribunais ${ }^{20}$.
Os requisitos formais de um título de crédito variam conforme as necessidades e a época. Como exemplo, Paolo Spada relata que na Itália era requisito essencial da letra de câmbio que nela constasse um selo, utilizado para fins tributários, o que atualmente não representa um óbice ${ }^{21}$. A taxa do selo variava conforme o valor do título ${ }^{22}$ e a ausência do mesmo importaria em nulidade da cambial, sem oportunidade de convalidação, sanção imposta para garantir o prévio recolhimento de tributos ${ }^{23}$. Outra regra que também é transitória e serve para certos títulos de crédito é a necessidade de numeração sequencial ${ }^{24}$. No mesmo sentido, o DecretoLei no 427/1969 que exigia o registro de Letras de Câmbio e Notas Promissórias, inclusive em branco, em 15 dias, em repartição indicada pelo Ministério da Fazenda, sob pena de nulidade ${ }^{25}$. Deve-se considerar o título como constituído de acordo com as regras do momento e do lugar de sua formação ${ }^{26}$, o que depende de particularidades constantes em cada ordenamento jurídico.

Em essência, considera-se que um título pode ser completo, incompleto ou em branco. Diz-se que é completo o título que encontra todos os requisitos essenciais e supletivos previstos em lei preenchidos no momento de sua emissão. São incompletos os títulos que não preenchem todos os requisitos previstos em lei ${ }^{27}$. São títulos em branco aqueles emitidos com a intenção do subscritor de que se promova o seu completamento conforme acordo de preenchimento ${ }^{28}$, podendo ser preenchidos até o momento de sua apresentação, por qualquer portador sucessivo ${ }^{29}$. Sem o devido e completo preenchimento do título, nenhum direito cambiário pode ser extraído ${ }^{30}$.

Paolo Spada afirma que não podem ser confundidos títulos em branco com os incompletos, na medida em que os últimos nasceram sem qualquer acordo para preenchimento, resultando na impossibilidade de se extrair os benefícios próprios de títulos de crédito, enquanto que os primeiros apenas dependem do efetivo completamento para serem extraídos tais efeitos ${ }^{31}$. Por outro lado, Alberto Asquini e Marcelo Vieira von Adamek acertadamente sustentam a irrelevância da distinção entre títulos incompletos e títulos em branco no caso de serem preenchidos, porque é utópico imaginar que alguém consiga distinguir faticamente as duas hipóteses. Além disso, o devedor imediato ${ }^{32}$ sempre pode alegar exceção ao portador, e o portador de boa-fé nunca pode sofrer exceção de devedor mediato ${ }^{33}$.

Diante destes aspectos, duas teorias explicam a formação do título de crédito, a saber: (a) teoria da criação; (b) teoria da emissão.

Pela teoria da criação, adotada no Brasil ${ }^{34}$, entende-se que o documento é considerado um título 
de crédito no momento em que é criado. Compreendese por criar que houve o preenchimento dos requisitos essenciais previstos no momento da elaboração do documento cambiário ${ }^{35}$. Por esta teoria, não importa se o título foi posto em circulação involuntariamente, como ocorre com o furto. Logo, atos de violência não invalidam o título ${ }^{36}$. Será perfeito o título com a sua simples criação ${ }^{37}$.

A teoria da emissão, por sua vez, importa admitir que o título emana seus efeitos a partir do momento em que posto em circulação. Por outro lado, a circulação involuntária, como ocorre com o furto, seria oponível inclusive ao portador de boa-fé $\mathrm{e}^{38}$. Os adeptos desta corrente amenizaram o seu rigor, em razão da gravidade das consequências pela oponibilidade de pagamento inclusive ao credor de boa-fés ${ }^{39}$.

No Brasil cabe certa controvérsia sobre a teoria constante no Código Civil. Isso porque o art. $891 \mathrm{faz}$ expressa menção à palavra emissão ${ }^{40}$. $\mathrm{Na}$ visão de Marcelo Vieira von Adamek não se detecta incorreção no emprego da palavra emissão no dispositivo citado, embora fosse mais adequado usar criação, isso porque nos títulos de crédito "incompletos" é natural que ocorra o completamento num momento sucessivo à emissão do documento, portanto fora da esfera de controle do signatário do título ${ }^{41}$. Além do mais o art. 887 do referido Código considera que é título de crédito o "documento necessário ao exercício do direito literal e autônomo nele contido" e que "somente produz efeito quando preencha os requisitos da lei" ${ }^{42}$, desimportando que tenha sido posto em circulação.

\section{REQUISITOS ESSENCIAIS DOS TÍTULOS DE CRÉDITO}

Títulos de crédito tem requisitos ${ }^{43}$ para que se extraiam seus efeitos cambiais ch4 $^{44}$ os quais podem variar conforme as necessidades da época, como já relatado, exemplificativamente, no caso do selo da letra de câmbio que era exigido para fins tributários.

Os formatos de títulos típicos mais comuns são reconhecíveis imediatamente por boa parte da população, como ocorre com o cheque, a duplicata e a nota promissória ${ }^{45}$. Dentre os elementos que os tornam identificáveis, a ausência de requisitos possuem pesos diferentes na formação do título, porquanto o que está em jogo é a identificabilidade do documento como título de crédito ${ }^{46}$.

Para Paolo Spada, os requisitos essenciais para que se considere que o documento é um título de crédito em branco são a assinatura e a fórmula cambiária (instrumento) ${ }^{47}$. A ausência destes elementos geraria problemas de identificabilidade do título. Marcelo
Vieira von Adamek diverge de Paolo Spada para assentar que o título de crédito depende de três requisitos, a saber, assinatura, instrumento com cláusula cambiária e pacto de preenchimento ${ }^{48}$. No entanto, parece equivocada a posição sustentada por Marcelo Adamek na medida em que o título preenchido sem qualquer pacto ainda assim apresentará validamente os seus efeitos ao terceiro de boa-fé.

\subsection{Assinatura}

Qualquer título de crédito precisa de uma assinatura cambiariamente utilizável ${ }^{49}$, sob pena de ser impossível inferir-se a vinculação de uma pessoa ao documento.

A Lei $n^{\circ}$ 6.304/1975 estendeu às duplicatas a possibilidade de usar chancela mecânica em substituição à assinatura. Igual possibilidade se verifica na Lei do Cheque $^{50}$. Tais mecanismos constituíram portas abertas ao uso de assinaturas eletrônicas que atualmente encontra expressa previsão legal no art. $889, \S^{\circ}$ do Código Civil ${ }^{51}$, o que se admite também nos títulos de crédito típicos ${ }^{52}$ pela aplicação subsidiária prevista no art. 903 do Código Civil ${ }^{53}$.

Supondo-se, por exemplo, que diversas pessoas tenham manifestado declarações cambiárias sobre uma letra de câmbio que não foi assinada por seu sacador, até a posterior assinatura não terá nenhum efeito cambiário extraível do referido documento. No entanto, a ulterior aposição de uma declaração cambiária originária importaria em efeitos retroativos, tornando passível de produção de efeitos todas as declarações derivadas postas no título ${ }^{54}$.

Algumas circunstâncias especiais podem importar em exceção pessoal do devedor principal contra os credores, como ocorre no caso de incapacidade do signatário, defeito de representação, caso de homônimo ou assinatura falsa ou imaginária. Embora tais exceções importem em objeção válida do devedor principal contra o credor, mesmo que seja um terceiro de boa-fé, a regularidade formal do título importa na validade do mesmo e na eficácia cambial ${ }^{55}$. Assim, a falsificação da assinatura desobriga o suposto signatário, mas não desobriga os demais signatários ${ }^{56}$.

Alberto Asquini sustenta a hipótese em que uma letra de câmbio tenha a indicação de um devedor com nome não apenas imaginário, mas absurdo ou irreal. Nestes casos, o próprio título seria inválido, porque não seria crível que alguém quisesse se vincular validamente ao mesmo ${ }^{57}$. Da mesma forma, a letra de câmbio com sacador de nome irreal não poderia ser válida, em especial na hipótese em que se indique na posição simultânea de sacado ${ }^{58}$.

A legislação brasileira não permite expressamente que seja aposta em título de crédito uma assinatura 
escaneada. No entanto, o STJ se deparou sobre tal caso e deixou de invalidar a nota promissória visto que o devedor não poderia se beneficiar da exceção a que deu causa (venire contra factum proprium) ${ }^{59}$.

Em problema semelhante ao da assinatura escaneada, Alberto Asquini afirma que a assinatura do devedor deve ser autógrafa, não se admitindo a aposição do polegar pelo analfabeto, ressalvandose a possibilidade de formação do título através de representante ${ }^{60}$.

\subsection{Instrumento}

Apesar da assinatura ser um requisito essencial para a formação de um título de crédito, não basta este elemento aposto em qualquer documento ${ }^{61}$. Para que seja um documento cambiário necessita de um instrumento que contenha uma cláusula cambiária ${ }^{62}$.

Os títulos típicos mais difundidos, como o cheque, são facilmente identificáveis pelo sujeito ${ }^{63}$ que, ao assiná-lo, sabe com facilidade que está se vinculando a um título de crédito. No entanto, o Código Civil prevê a possibilidade de criação de títulos de crédito atípicos no art. 889 do $\mathrm{CC}^{64}$, hipótese em que não existe cláusula cambiária universal ${ }^{65}$.

Marcelo Vieira von Adamek sustenta que o título de crédito atípico necessita da expressão "título de crédito" além de mencionar os direitos conferidos no documento, com a finalidade de restar claro a qualquer pessoa que se trata de uma cambial ${ }^{66}$, na medida em que importa em efeitos jurídicos mais rígidos que as relações contratuais. Danilo Borges dos Santos Gomes de Araújo acertadamente diverge de Adamek e afirma que é desnecessário ao documento cambiário atípico que contenha a denominação de "título de crédito", porquanto basta a indicação clara e precisa dos direitos conferidos pelo mesmo ${ }^{67}$. Igualmente, Paolo Spada sustenta que basta a identificabilidade do documento como título de crédito ${ }^{68}$. Por fim, Alberto Asquini se coloca em posição intermediária para afirmar que os títulos de crédito atípicos devem conter um "título" que apenas não deixe dúvida nenhuma de que se trata de uma cambial, visto que a obrigação assumida é bastante rigorosa ${ }^{69}$.

\subsection{Pacto de preenchimento}

Pode-se dividir o pacto de preenchimento ${ }^{70} \mathrm{em}$ duas espécies: (a) com a finalidade de completar título em branco; (b) com a finalidade de enriquecimento do teor documental ${ }^{71}$.

Na hipótese de se completar título em branco, é pressuposto lógico que na sua emissão o documento cambiário não esteja completo para fins de se extrair seus efeitos jurídicos próprios ${ }^{72}$. Por outro lado, caso seja um pacto de preenchimento para enriquecimento do teor documental, conclui-se que o título está completo para gerar os efeitos cambiais, embora com conteúdo ainda diverso daquele ajustado pelas partes.

Como exemplo da segunda hipótese, Gemma Angélica Sánchez Lerma expõe que a jurisprudência espanhola costuma entender que a ausência de preenchimento da moeda não é omissão invalidante ${ }^{73}$. Compreende-se que a moeda é aquela normalmente utilizada no lugar da emissão. No caso da Espanha presumia-se, à epoca, em pesetas, segundo doutrina e jurisprudência. Portanto, a faculdade de preenchimento pode distorcer gravemente a obrigação constante no título caso a moeda combinada não coincida com pesetas ou seja preenchida em desconformidade com o combinado. Salvo essas hipóteses, trata-se de direito potestativo a faculdade de preencher o título, o qual seria apenas enriquecido, visto que já apresentaria os elementos necessários para serem extraídos os efeitos cambiários $^{74}$.

Tullio Ascarelli sustenta que somente é possível o preenchimento sucessivo de títulos de crédito abstratos, como o cheque e a nota promissória ${ }^{75}$, não se aplicando aos títulos causais ${ }^{76}$. Isto porque os títulos causais são emitidos com base em determinado negócio realizado e deve apenas espelhar os dados constantes no mesmo ${ }^{77}$. Como exemplo, a duplicata é extraída com base na duplicação dos dados constante na fatura emitida. No entanto, corretamente Alberto Asquini esclarece que nada impede que um documento cambiário causal seja emitido em branco e a causa do título sirva justamente para embasar os termos do acordo de preenchimento ${ }^{78}$. Ademais, a causa é irrelevante ao terceiro de boa-fé, seja nos títulos abstratos, seja nos títulos causais ${ }^{79}$.

O referido pacto é um ajuste feito externamente ao próprio título, conferindo-lhe uma natureza extracartular ${ }^{80}$. Significa dizer que a sua inexistência ou descumprimento não afetam os efeitos cambiários, em especial frente ao terceiro de boa-fé ${ }^{81}$.

Alberto Asquini expõe que o preenchimento do título em conformidade com o pacto deve ser realizado no prazo decadencial de três anos a contar da emissão ${ }^{82}$, lapso temporal que guarda relação com o prazo prescricional do próprio título de crédito. Aplicando-se idêntico raciocínio, poderia se dizer que decai em três anos o prazo para completar letras de câmbio ${ }^{83}$, notas promissórias ${ }^{84}$ e duplicatas ${ }^{85}$. Por outro lado, tal linha induz a compreender que o prazo para completamento de cheques é menor, visto que o prazo prescricional é de seis meses a contar da expiração do prazo de apresentação ${ }^{86}$, portanto inferior a um ano. 
A morte ou falência do subscritor não priva o portador do direito de preencher o título de crédito ${ }^{87}$ dentro do prazo decadencial. Da mesma forma, o poder de preenchimento não pode ser revogado ${ }^{88}$.

\subsubsection{Nome do beneficiário}

O Código Civil não impõe que haja imediato preenchimento do nome do beneficiário em título de crédito $^{89}$, em especial quando se admite títulos ao portador. Arnaldo Bruschettini sustenta que não há problema que um título seja "incompleto" e não conste o nome do credor, mas se a lei exige que o título seja ao portador, nem uma vontade expressa poderia afastar tal característica, não se permitindo que seja validamente posto o nome do beneficiário ${ }^{90}$. Em complemento, Paolo Spada assinala que a cambial com credor em branco não é título nos locais onde não é admitido título ao portador ${ }^{91}$.

Supondo que certo título de crédito seja entregue ao beneficiário sem o preenchimento do seu nome, pode vir a circular por diversas pessoas. Caso o último portador coloque o seu nome como primeiro e único beneficiário, resulta na criação formal de uma relação cambiária imediata entre devedor e atual credor do título. Admitindo-se que o título viesse a ser preenchido com a indicação do primeiro beneficiário e a aposição nominal dos sucessivos endossatários, a relação entre o devedor e o atual credor seria mediata. A diferença está em que nas relações imediatas é cabível a oposição de exceções pessoais, inclusive por preenchimento abusivo $^{92}$, para não pagar a dívida constante no documento cambiário ${ }^{93}$.

\subsubsection{Data de emissão}

O Código Civil exige como requisito essencial para qualquer título de crédito que seja mencionada a data de emissão $0^{94}$. No mesmo sentido já houve reconhecimento pelo STJ de que este é um requisito essencial para a emissão de notas promissórias ${ }^{95}$. Mencionar o momento da emissão é relevante em nosso ordenamento para verificar a capacidade do emitente e do beneficiário ${ }^{96}$, calcular vencimento em alguns casos e contar o prazo decadencial para o exercício do direito de preencher o documento cambiário ${ }^{97}$. Por outro lado, nada impede que um título circule com a data da emissão em branco, para posterior preenchimento pelo portador, de forma que não se trata de requisito essencial para que se considere formado o título ${ }^{98}$.

No caso de cheque, título de crédito que representa ordem de pagamento à vista, tornou-se habitual que as partes formulem convenção de prazo denominada de cheque pós-datado (conhecido como pré-datado) ${ }^{99}$. Mesmo que seja convencionada certa data para considerar-se como o seu vencimento, importa apenas a data de emissão, mencionada no campo próprio, para contagem de prazo prescricional ${ }^{100}$.

A data de emissão alcança a função lógica de permitir supor a data do vencimento, caso este dado não seja mencionado ${ }^{101}$. Alberto Asquini retrata que na Itália era requisito essencial a data do vencimento, mas não a data de emissão do documento cambiário ${ }^{102}$. Teoricamente, não haveria nenhum relevante prejuízo ao título em que constasse apenas o vencimento, mas não a data de emissão ${ }^{103}$, partindo-se mais de uma opção legislativa. O STJ analisou caso em que era incontroversa a data de emissão de uma nota promissória, mas julgou-a inexigível em razão da ausência de expressa menção da referida data no documento cambiário ${ }^{104}$.

Em relação à análise da capacidade, Arnaldo Bruschettini lança dois exemplos de incapacidade parcial, a saber, o menor de idade e a mulher casada (este último que era, à época, um exemplo cabível) ${ }^{105}$. Tais hipóteses podem invalidar o título, sendo a data de emissão o elemento temporal que baliza a análise. Considerando que seria fácil dissimular a data de emissão, não é juridicamente adequado simplesmente ignorar a data efetiva de emissão ${ }^{106}$, a qual prepondera e pode ser provada por qualquer meio ${ }^{107}$.

O STJ teve a oportunidade de analisar caso de relatoria do Ministro Sálvio de Figueiredo Teixeira em que uma nota promissória foi emitida, mas que a data de emissão mencionada no título era posterior ao óbito do próprio devedor. Embora não houvesse dúvida da autenticidade da assinatura do emitente, mas apenas da data efetiva de emissão, por maioria acolheu-se a posição de que o título era nulo em razão do "rigor formal como elemento que integra a própria definição dos títulos de crédito". Assim, "o preenchimento errôneo da data de emissão da nota promissória equivale a não constar a data que a cambial foi passada" 108 . Corretamente, manifestaram divergência os Ministros César Asfor Rocha e Ruy Rosado de Aguiar Júnior entendendo tratar-se de "exagerada ênfase a uma simples formalidade, ter por nula nota promissória" em que há divergência na data de emissão, embora não se controverta a autenticidade da assinatura do emitente ${ }^{109}$.

Arnaldo Bruschettini afirma que não basta a análise da capacidade do devedor, pois é essencial a análise da finalidade do título de crédito. Supondo que o relativamente capaz tenha emitido título, deve ser observado que será nulo/anulável se o objetivo era de contrair mútuo, mas será válido e eficaz se tinha como fim o simples pagamento de dívida já contraída ${ }^{110}$. 


\subsubsection{Lugar da emissão}

O lugar de emissão não é requisito essencial no Direito Cambiário, embora sua ausência seja passível de sensíveis problemas teóricos e práticos.

Caso, exemplificativamente, falte a indicação do lugar de emissão ou de pagamento na nota promissória, resolve-se pela previsão constante no art. 76 do Decreto n. ${ }^{\circ} 57.663 / 1966^{111}$ que indica como suprir eventual omissão ${ }^{112}$. O Código Civil criou regra simplificada para suprir a omissão e afirma que "considera-se lugar de emissão e de pagamento, quando não indicado no título, o domicílio do emitente" ${ }^{113}$. Desta forma, ao saber o domicílio do emitente, seria possível inferir-se o lugar da emissão.

A importância da definição do lugar de emissão está em saber qual é o ordenamento jurídico aplicável ${ }^{114}$, visto que se aplicará o Direito Brasileiro aos títulos emitidos no Brasil, os quais são assim presumidos se, na ausência de indicação, o devedor for domiciliado no Brasil. Embora haja razoável uniformidade do Direito Cambiário no plano internacional, podem ocorrer divergências juridicamente relevantes para os casos concretos.

Por outro lado, convém recordar que o conceito de domicílio não permite, necessariamente, aferir uma unicidade, na medida em que em razão do disposto no art. 71 do Código Civil ${ }^{115}$ uma pessoa natural pode possuir mais de um domicílio ${ }^{116}$, assim como também é possível a pluralidade de domicílios para as pessoas jurídicas ${ }^{117}$.

\subsubsection{Preenchimento e exercício da pretensão}

Para que seja possível exercer os direitos inerentes aos título de crédito - protesto e execução - seus requisitos formais devem estar plenamente preenchidos, conforme parte considerável da doutrina ${ }^{118}$.

Marcelo Vieira von Adamek sustenta que os julgados mais recentes dos Tribunais têm seguido "esta última orientação mais liberal, admitindo que, mesmo depois de proposta uma ação malfadada, com apoio em título incompleto, o portador possa desentranhar o documento, completá-lo e voltar a juízo" 119 . Com a devida vênia, embora se acredite que esta suposta visão mais "liberal" seja a mais adequada, não parece ser a orientação atual, inclusive do STJ ${ }^{120}$. Apenas registre-se que não parece fazer sentido impedir o preenchimento de um título simplesmente porque foi proposta uma ação com o documento ainda não completamente preenchido, como se fosse uma aparente prova de uma incompletude que nada mais é do que algo permitido. Entre os precedentes que fundamentam este entendimento consta o RE $\mathrm{n} \mathbf{0} \mathbf{4} .945$ que afirma que "seu preenchimento pelo credor é possível antes de surgir o título em público", isto porque "podia ser feito, antes de surgir em público, na ação de cobrança ou em protesto" 121 . Em outro julgado, que parece ser o precursor, de lavra do Min. Nelson Hungria, extrai-se que o motivo da Súmula no 387 do STF está em que a doutrina da época não admitia o posterior preenchimento de nota promissória, a qual, pelo então vigente art. 54, §4을 do Decreto n. ${ }^{\circ}$ 2.044/1908 ${ }^{122}$, não permitia o completamento do título após a sua emissão ${ }^{123}$. Ocorre que atualmente é possível preencher a posteriori as notas promissórias ${ }^{124}$, parecendo não mais subsistir o fundamento da orientação jurisprudencial.

\subsubsection{Preenchimento, circulação e oponibilidade}

Formou-se a premissa neste trabalho de que títulos de crédito em branco podem ser preenchidos posteriormente à emissão do documento cambiário ${ }^{125}$. Tal completamento retroage ao momento originário ${ }^{126}$, mesmo que seja superveniente à sua emissão a própria declaração autônoma originária prestada pelo devedor e será legítimo, desde que realizado em conformidade com o acordo de preenchimento ${ }^{127}$. Acaso se forme uma declaração cambiária transbordante aos limites do pacto de preenchimento, a consequência é a ineficácia do conteúdo que extrapola o pactuado, mantendo-se hígido o título no restante 128 .

Em síntese, a oponibilidade, inclusive por completamento abusivo ou inexistência de pacto de preenchimento pode ser feito sempre nos títulos que não circularam por meio de endosso ${ }^{129}$, porquanto no âmbito das relações imediatas - neste caso, a relação fundamental -, sempre será oponível a exceção de preenchimento abusivo, cujo ônus da prova caberá ao devedor ${ }^{130}$. Anote-se que o questionamento por preenchimento abusivo ataca a obrigação cambiária, mas não o contrato subjacente existente entre as $\operatorname{partes}^{131}$. Por outro lado, por segurança das relações negociais, após a circulação do título de crédito, por meio de endosso regular, portanto, descolando-se o título da relação fundamental que lhe deu origem (autonomia) ${ }^{132}$, não se admite a formulação de oposição ao pagamento nas relações mediatas ${ }^{133}$, inclusive quanto ao teor do pacto de preenchimento, salvo nos casos de má-fée ${ }^{134}$.

Cumpre esclarecer que a exceção contra o preenchimento abusivo de um título de crédito apenas pode ser alegado pelo devedor (principal ou indireto) referente ao conteúdo preenchido posteriormente ${ }^{135}$. Portanto, não se admite que um dos devedores da cadeia de endossos reclame posteriormente de algum dos elementos do título (como o valor indevidamente 
aumentado) se à época já constava a distorção ao pacto de preenchimento e, desta forma, tomou proveito da situação.

A doutrina faz distinção entre má-fé e culpa grave. Isso porque na Lei Uniforme de Genebra, que trata de letras de câmbio e notas promissórias consta que "se uma letra incompleta no momento de ser passada tiver sido completada contrariamente aos acordos realizados não pode a inobservância desses acordos ser motivo de oposição ao portador, salvo se este tiver adquirido a letra de má-fé ou, adquirindo-a, tenha cometido uma falta grave"136. Por outro lado, a expressão falta grave não consta no Código Civil, aplicável subsidiariamente aos títulos de crédito $^{137}$, que apenas dispõe que é oponível exceção ao preenchimento abusivo ou decorrente de pacto de preenchimento inexistente se o "terceiro portador ..., ao adquirir o título, tiver agido de má-fé"138. Alberto Asquini menciona que o art. 14 da Lei Cambiária italiana "equipara" má-fé com culpa grave $^{139}$. Talvez seja mais adequado apenas mencionar que tal disposição apenas admite oposição centrada nas duas hipóteses ${ }^{140}$. Considerando a distinção legislativa, convém esclarecer as diferenças entre as hipóteses de má-fé e de culpa grave (ou falta grave).

A diferença entre má-fé e culpa grave reside em que na primeira existe ciência dos vícios contidos nas relações jurídicas que embasam certa declaração cambial, com o conhecimento, portanto, da violação do acordo de preenchimento ${ }^{141}$, e na segunda o portador não usa a diligência necessária para saber o exato conteúdo do acordo de preenchimento ${ }^{142}$.

A existência de má-fé por parte do adquirente verifica-se no momento da transferência do título ${ }^{143}$. Isso porque "si la mala fe sobrevenida fuera relevante nadie querría adquirir una letra en blanco por temor a perder sus expectativas en el derecho tal y como inicialmente ha sido configurado, precisamente por la posibilidad de conocer posteriormente el verdadero contenido de tal derecho"144. Portanto, o superveniente conhecimento pelo portador sobre exceções oponíveis pelo emitente de uma nota promissória contra o beneficiário original do título não retira-lhe a condição de terceiro de boa-fé. Da mesma forma, caso o portador, agindo de boa-fé, tenha apenas cumprido instruções de seu predecessor, não pode ficar em pior situação do que se fosse preenchido pelo predecessor ${ }^{145}$, mesmo que o portador venha a descobrir antes do preenchimento sobre as exceções oponíveis. É preciso tutelar não apenas o portador de títulos completos, mas também de documentos cambiários ainda em branco ${ }^{146}$.

Paolo Spada adverte que o abuso de preenchimento pode resultar de ato omissivo ou comissivo. Desta forma, incorre em igual abuso o portador que não preenche a data de vencimento e usa o título como à vista, como também assim sucede com o portador que preenche o título com data diversa daquela que foi convencionada ${ }^{147}$.

$\mathrm{O}$ terceiro que adquire título já preenchido não está obrigado a perquirir se o conteúdo do documento foi preenchido em única vez ou sucessivamente. Por outro lado, quem adquire um título em branco está obrigado a conhecer os termos do pacto para promover o adequado preenchimento da cambial. Assim, para analisar boa ou má-fé é possível exigir as "actuaciones normales que le conduzcan al conocimiento del contenido de la obligación adquirida y que en función de este conocimiento, complete adecuadamente el título, o bien transmita adecuadamente la facultad de completamiento" 148 .

\section{CONCLUSÃO}

A análise dos títulos de crédito em branco e incompletos demonstra discussões jurídicas relevantes que se travam ao longo dos tempos dentro de matéria que passa por momento de profunda reflexão.

O Direito Cambiário privilegiou a literalidade da cártula como mecanismo para sedimentar a autonomia das declarações cambiais e a inoponibilidade de exceções pessoais ao terceiro de boa-fé, facilitando a circulação dos títulos de crédito e ampliando a segurança jurídica do credor. Ocorre que a estrutura focada na circulação por meio de cártulas talvez não seja mais uma função de relevante importância como foi outrora, em especial frente a novos meios de pagamento e de circulação de crédito.

Ressalvando-se particularidades de cada ordenamento jurídico, todo título de crédito, para ser criado, precisa de dois elementos, a saber, uma assinatura cambiariamente utilizável e um instrumento com cláusula cambiária. Além desses dois elementos, torna-se relevante que exista um pacto de preenchimento, sendo este um ajuste extracartular que define os termos do completamento do título. Pode inexistir o referido pacto ou este ser objeto de abuso por parte do portador, importando em distorções relevantes no título de crédito, fato este que exige compreensão detalhada dos efeitos jurídicos daí derivados.

O Direito Cambiário demonstra uma origem claramente formalista, mas os exemplos colhidos na jurisprudência mostram uma tensão em razão dos magistrados que buscam reduzir o rigor formal em função de uma justiça material para o caso concreto. De certa forma, é uma tensão que torna necessário repensar os próprios pressupostos teóricos da matéria, os quais devem ser adaptados à nova realidade. 


\section{REFERÊNCIAS}

AHUMADA, Raul Cervantes. Titulos y operaciones de credito. 8. ed. México: Herrero, 1972.

AZEVEDO, Álvaro Villaça. Teoria Geral do Direito Civil. São Paulo: Atlas, 2012.

ASCARELLI, Tullio. Teoria geral dos títulos de crédito. Campinas: Servanda, 2013.

ASQUINI, Alberto. Lezioni di Diritto Commerciale: titoli di credito e in particolare cambiale e titoli bancari di pagamento. Pádua: CEDAM, 1951.

BASSO, Maristela. Curso de Direito Internacional Privado. 2. ed. São Paulo: Atlas, 2011.

BRUSCHETTINI, Arnaldo. Trattato dei titoli al portatore. Turim: Fratelli Bocca, 1898

CAVALLI, Cássio Machado. Contornos dogmáticos da teoria geral dos títulos de crédito e a tecnologia da informação. Revista dos Tribunais, n. 919, p. 199-242, 2012.

DE LUCCA, Newton. Aspectos da teoria geral dos títulos de crédito. São Paulo: Pioneira, 1979.
DE LUCCA, Newton. A influência do pensamento de Tullio Ascarelli em matéria de títulos de crédito no Brasil. Revista Magister de Direito Empresarial, Concorrencial e do Consumidor, n. 1, p. 17-35, 2005.

DOLINGER, Jacob. Direito Internacional Privado: parte geral. 10. ed. Rio de Janeiro: Forense, 2012.

FARIA, Werter R. Cheque: as convenções de Genebra e o direito brasileiro. Porto Alegre, SAFE, 1978.

GORGA, Érica; SICA, Lígia Paula Pinto. Estudos avançados de Direito Empresarial: títulos de crédito. Rio de Janeiro: Elsevier, 2013

LÔBO, Paulo. Direito Civil: parte geral. 3. ed. São Paulo: Saraiva, 2012.

MESSINEO, Francesco. I titoli di credito. 2. ed. Pádua: CEDAM, 1933. Vol. I.

PELLIZZI, Giovanni. I titoli di credito. Milão: Giuffrè, 1980.

SPINELLI, Luís Felipe. Os títulos de crédito eletrônicos e as suas problemáticas nos planos teórico e prático. Revista Jurídica Empresarial, n. 16, p. 11-52, 2010.

\section{NOTAS}

ASCARELLI, Tullio. Teoria geral dos títulos de crédito. Campinas: Servanda, 2013. p. 33.

2 Ibidem. p. 34

3 Ibidem. p. 74; Para alcançar este fim, são vocacionados a receber múltiplas declarações unilaterais de vontade, como consta em ADAMEK, Marcelo Vieira von. Títulos de crédito incompletos (títulos típicos e atípicos) in GORGA, Érica; SICA, Lígia Paula Pinto. Estudos avançados de Direito Empresarial: títulos de crédito. Rio de Janeiro: Elsevier, 2013. p. 197.

4 DE LUCCA, Newton. Aspectos da teoria geral dos títulos de crédito. São Paulo: Pioneira, 1979. p. 28

5 Ibidem. p. 28.

6 ASQUINI, Alberto. Lezioni di Diritto Commerciale: titoli di credito e in particolare cambiale e titoli bancari di pagamento. Pádua: CEDAM, 1951.p. 185.

7 DE LUCCA, Newton. Aspectos da teoria geral dos títulos de crédito. São Paulo: Pioneira, 1979. p. 28; Assinala Newton de Lucca que algum grau de padronização foi obtido no plano internacional em razão da Lei Uniforme de Genebra, como consta na p. 39.

8 Relação obrigacional que dá origem ao título de crédito. Além da relação fundamental, a cada transferência de título de um credor para outro, como ocorre no endosso, há um negócio jurídico subjacente.

9 ASCARELLI, Tullio. Teoria geral dos títulos de crédito. Campinas: Servanda, 2013. p. 73-74

10 Ibidem. p. 28-29.

${ }^{11}$ Ibidem. p. 29

12 SPINELLI, Luís Felipe. Os títulos de crédito eletrônicos e as suas problemáticas nos planos teórico e prático. Revista Jurídica Empresarial, n. 16, 2010, p. 11-52; Newton de Lucca diz que talvez os títulos de crédito venham a desaparecer e que não haveria porque chorar pelo "defunto", porque cumpriu a sua função e nasceriam novas formas de circulação de riquezas.

13 ASCARELLI, Tullio. Teoria geral dos títulos de crédito. Campinas: Servanda, 2013. p. 439-440; ARAÚJO, Danilo Borges dos Santos Gomes de. $\mathrm{O}$ formalismo dos títulos de crédito como segurança jurídica in GORGA, Érica; SICA, Lígia Paula Pinto. Estudos avançados de Direito Empresarial: títulos de crédito. Rio de Janeiro: Elsevier, 2013. p. 02.

14 Apenas como exemplos: BRUSCHETTINI, Arnaldo. Trattato dei titoli al portatore. Turim: Fratelli Bocca, 1898; PELLIZZI, Giovanni. I titoli di credito. Milão: Giuffrè, 1980; GORGA, Érica; SICA, Lígia Paula Pinto. Estudos avançados de Direito Empresarial: títulos de crédito. Rio de Janeiro: Elsevier, 2013; LERMA, Gemma Angélica Sánchez. La letra de cambio en blanco. Barcelona: Bosch, 1999.

${ }^{15}$ Decreto $n^{\circ}-57.663 / 1966$ - Art. 1을 A letra contém: 1 - A palavra «letra» inserta no próprio texto do título é expressa na língua empregada para a redação desse título; 2 - $\mathrm{O}$ mandato puro e simples de pagar uma quantia determinada; 3 - O nome daquele que deve pagar (sacado); 4 A época do pagamento; 5 - A indicação do lugar em que se deve efetuar o pagamento; $6-\mathrm{O}$ nome da pessoa a quem ou a ordem de quem deve ser paga; 7 - A indicação da data em que, e do lugar onde a letra é passada; 8 - A assinatura de quem passa a letra (sacador).

${ }^{16}$ Decreto $\mathrm{n}^{\mathrm{o}}$ 57.663/1966 - Art. 75. A nota promissória contém: 1 - Denominação "Nota Promissória" inserta no próprio texto do título e expressa na língua empregada para a redação desse título; 2 - A promessa pura e simples de pagar uma quantia determinada; 3 - A época do pagamento; 4 - A indicação do lugar em que se deve efetuar o pagamento; 5 - O nome da pessoa a quem ou a ordem de quem deve ser paga; 6 - A indicação da data em que e do lugar onde a nota promissória é passada; 7 -A assinatura de quem passa a nota promissória (subscritor).

17 Lei 7.357/1985 - Art. 1o O cheque contêm: I- a denominação "cheque" inscrita no contexto do título e expressa na língua em que este é redigido; II - a ordem incondicional de pagar quantia determinada; III - o nome do banco ou da instituição financeira que deve pagar (sacado); IV - a indicação do lugar de pagamento; $\mathrm{V}-\mathrm{a}$ indicação da data e do lugar de emissão; VI - a assinatura do emitente (sacador), ou de seu mandatário com poderes especiais. Parágrafo único - A assinatura do emitente ou a de seu mandatário com poderes especiais pode ser constituída, na forma de legislação específica, por chancela mecânica ou processo equivalente.

${ }^{18}$ Lei $5.474 / 1968$ - Art. $2^{\mathrm{O}}$ No ato da emissão da fatura, dela poderá ser extraída uma duplicata para circulação como efeito comercial, não sendo admitida qualquer outra espécie de título de crédito para documentar o saque do vendedor pela importância faturada ao comprador. $\S 1^{\circ} \mathrm{O} A$ duplicata conterá: I - a denominação «duplicata», a data de sua emissão e o número de ordem; II - o número da fatura; III - a data certa do vencimento ou a declaração de ser a duplicata à vista; IV - o nome e domicílio do ven dedor e do comprador; $\mathrm{V}$ - a importância a pagar, em algarismos e por extenso; VI - a praça de pagamento; VII - a cláusula à ordem; VIII - a declaração do reconhecimento de sua exatidão e da obrigação de pagá-la, a ser assinada pelo comprador, como aceite, cambial; IX - a assinatura do emitente

${ }^{19}$ ASCARELLI, Tullio. Teoria geral dos títulos de crédito. Campinas: Servanda, 2013. p. 64; ARAUJO, Danilo Borges dos Santos Gomes de. O formalismo dos títulos de crédito como segurança jurídicain GORGA, Érica; SICA, Lígia Paula Pinto. Estudos avançados de Direito Empresarial: títulos de crédito. Rio de Janeiro: Elsevier, 2013. p. 05.

${ }^{20}$ Como exemplo desta flexibilização, o STJ passou a admitir a instrução de execuções com boletos bancários em substituição às "duplicatas virtuais" (STJ, 3- Turma, REsp no 1.024.691/PR, Rel. Min. Nancy Andrighi, julgado em 22/03/2011)

21 SPADA, Paolo. Questioni in tema di cambiale in bianco in PELLIZZI, Giovanni. I titoli di credito. Milão: Giuffrè, 1980. p. 258.

22 Arnaldo Bruschettini assinala que o direito constante de um título pode ser dinheiro ou de outra natureza, inclusive entrega de bem ou serviço 
e que apenas não seria possível a cessão de posse porque a posse não é cessível, como consta em BRUSCHETTINI, Arnaldo. Trattato dei titoli al portatore. Turim: Fratelli Bocca, 1898. p. 358.

${ }^{23}$ ASQUINI, Alberto. Lezioni di Diritto Commerciale: titoli di credito e in particolare cambiale e titoli bancari di pagamento. Pádua: CEDAM, 1951. p. 187.

${ }^{24}$ BRUSCHETTINI, Arnaldo. Trattato dei titoli al portatore. Turim: Fratelli Bocca, 1898. p. 370

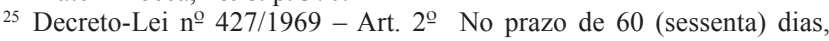
da data da publicação dêste Decreto-lei, deverão ser registradas na repartição competente, definida pelo Ministério da Fazenda, tôdas as notas promissórias e letras de câmbio emitidas até a publicação dêste Decreto-lei, sob pena de nulidade dêsses títulos de crédito. $\S 1^{\circ}$ As notas promissórias e letras de câmbio emitidas a partir da data da publicação dêste Decreto-lei, deverão, sob a mesma pena de nulidade, ser registradas no prazo de 15 (quinze) dias de sua emissão; No mesmo sentido: STF, $2^{\mathrm{a}}$ Turma, RE no ${ }^{-}$81.996/SP, Rel. Min. Cordeiro Guerra, julgado em 09/04/1976

${ }^{26}$ ASCARELLI, Tullio. Teoria geral dos titulos de crédito. Campinas: Servanda, 2013. p. 435.

27 ASQUINI, Alberto. Lezioni di Diritto Commerciale: titoli di credito e in particolare cambiale e titoli bancari di pagamento. Pádua: CEDAM, 1951. p. 99; Gemma Angélica Sánchez Lerma afirma que para alguns autores o preenchimento de um título incompleto equivale a uma falsificação, como consta em LERMA, Gemma Angélica Sánchez. La letra de cambio en blanco. Barcelona: Bosch, 1999. p. 276.

${ }_{28}$ ADAMEK, Marcelo Vieira von. Títulos de crédito incompletos (títulos típicos e atípicos) in GORGA, Érica; SICA, Lígia Paula Pinto. Estudos avançados de Direito Empresarial: títulos de crédito. Rio de Janeiro: Elsevier, 2013. p. 201; Observa Alberto Asquini que a finalidade de emitir um título em branco está normalmente relacionado a crédito ainda não constituído, como consta em ASQUINI, Alberto. Lezioni di Diritto Commerciale: titoli di credito e in particolare cambiale e titoli bancari di pagamento. Pádua: CEDAM, 1951. p. 207; o acordo de preenchimento já foi tratado no passado como contrato de mandato, entendendo-se que o responsável pelo preenchimento seria mero mandatário do devedor, como consta em SPADA, Paolo. Questioni in tema di cambiale in bianco in PELLIZZI, Giovanni. I titoli di credito. Milão: Giuffrè, 1980. p. 259; Igual referência ao mandato ocorre em julgados recentes no Brasil, como consta em TJ-RS, $10^{\text {an }}$ Câmara Cível, Apelação Cível no 70055883052, Rel. Des. Túlio de Oliveira Martins, julgado em 24/04/2014; Paolo Spada menciona que uma sentença de 1939 considerou o pacto de preenchimento como condição suspensiva, como consta em SPADA, Paolo. Questioni in tema di cambiale in bianco in PELLIZZI, Giovanni. I titoli di credito. Milão: Giuffrè, 1980. p. 262.

29 ASCARELLI, Tullio. Teoria geral dos titulos de crédito. Campinas: Servanda, 2013. p. 65-66 e 69; Marcelo Vieira von Adamek sustenta que títulos de crédito em branco seriam documentos cambiários de formação sucessiva, colocados em circulação por vontade do próprio signatário, como consta em ADAMEK, Marcelo Vieira von. Títulos de crédito incompletos (títulos típicos e atípicos) in GORGA, Érica; SICA, Lígia Paula Pinto. Estudos avançados de Direito Empresarial: títulos de crédito. Rio de Janeiro: Elsevier, 2013. p. 202.

${ }^{30}$ LERMA, Gemma Angélica Sánchez. La letra de cambio en blanco. Barcelona: Bosch, 1999. p. 252.

31 SPADA, Paolo. Questioni in tema di cambiale in bianco in PELLIZZI, Giovanni. I titoli di credito. Milão: Giuffrè, 1980. p. 254; No mesmo sentido, LERMA, Gemma Angélica Sánchez. La letra de cambio en blanco. Barcelona: Bosch, 1999. p. 275.

32 Entende-se por relação mediata aquela que não é direta entre devedor e credor. Por exemplo, na emissão de nota promissória, o emitente $X$ emite o título destinando como credor o beneficiário Y. Posteriormente, $\mathrm{Y}$ endossa o título para Z. Existe relação imediata (direta) entre X e Y, bem como entre $\mathrm{Y}$ e Z, mas a relação é mediata entre X e Z.

33 ASQUINI, Alberto. Lezioni di Diritto Commerciale: titoli di credito e in particolare cambiale e titoli bancari di pagamento. Pádua: CEDAM, 1951. p. 208; ADAMEK, Marcelo Vieira von. Títulos de crédito incompletos (títulos típicos e atípicos) in GORGA, Érica; SICA, Lígia Paula Pinto. Estudos avançados de Direito Empresarial: títulos de crédito. Rio de Janeiro: Elsevier, 2013. p. 202-204; Mesmo no caso de títulos incompletos, nos quais inexiste pacto de preenchimento, como constam em LERMA, Gemma Angélica Sánchez. La letra de cambio en blanco. Barcelona: Bosch, 1999. p. 277.

${ }^{34}$ ARAÚJO, Danilo Borges dos Santos Gomes de. O formalismo dos títulos de crédito como segurança jurídica in GORGA, Érica; SICA, Lígia Paula Pinto. Estudos avançados de Direito Empresarial: títulos de crédito. Rio de Janeiro: Elsevier, 2013. p. 11.
${ }^{35}$ Ibidem. p. 09

${ }^{36}$ BRUSCHETTINI, Arnaldo. Trattato dei titoli al portatore. Turim: Fratelli Bocca, 1898. p. 352.

37 ASCARELLI, Tullio. Teoria geral dos títulos de crédito. Campinas: Servanda, 2013. p. 426.

38 ARAÚJO, Danilo Borges dos Santos Gomes de. O formalismo dos títulos de crédito como segurança jurídica in GORGA, Érica; SICA, Lígia Paula Pinto. Estudos avançados de Direito Empresarial: títulos de crédito. Rio de Janeiro: Elsevier, 2013. p. 09-10.

39 ASCARELLI, Tullio. Teoria geral dos títulos de crédito. Campinas: Servanda, 2013. p. 425

${ }^{40} \mathrm{CC}$ - Art. 891. O título de crédito, incompleto ao tempo da emissão, deve ser preenchido de conformidade com os ajustes realizados. Parágrafo único. O descumprimento dos ajustes previstos neste artigo pelos que deles participaram, não constitui motivo de oposição ao terceiro portador, salvo se este, ao adquirir o título, tiver agido de má-fé.

41 ADAMEK, Marcelo Vieira von. Títulos de crédito incompletos (títulos típicos e atípicos) in GORGA, Érica; SICA, Lígia Paula Pinto. Estudos avançados de Direito Empresarial: títulos de crédito. Rio de Janeiro: Elsevier, 2013. p. 198

${ }^{42} \mathrm{CC}-$ Art. 887. O título de crédito, documento necessário ao exercício do direito literal e autônomo nele contido, somente produz efeito quando preencha os requisitos da lei.

${ }^{43}$ Que se encontram expressos nos arts. 887 e 888 do CC em nosso ordenamento jurídico, como consta em ARAÚJO, Danilo Borges dos Santos Gomes de. O formalismo dos títulos de crédito como segurança jurídica in GORGA, Érica; SICA, Lígia Paula Pinto. Estudos avançados de Direito Empresarial: títulos de crédito. Rio de Janeiro: Elsevier, 2013. p. 07.

44 Título em formação é ineficaz e precisa de ulterior preenchimento para ter direitos exercidos em juízo, como consta em ADAMEK, Marcelo Vieira von. Títulos de crédito incompletos (títulos típicos e atípicos) in GORGA, Érica; SICA, Lígia Paula Pinto. Estudos avançados de Direito Empresarial: títulos de crédito. Rio de Janeiro: Elsevier, 2013. p. 212; LERMA, Gemma Angélica Sánchez. La letra de cambio en blanco. Barcelona: Bosch, 1999. p. 251: "Aunque la letra en blanco ya contenía obligaciones que se regían por el Derecho Cambiario lo cierto es que en el caso de que las lagunas documentales presentadas por el documento recaigan sobre elementos esenciales de la letra de cambio, si no se da el completamiento, de poco habrá servido admitir que tales obligaciones derivadas de la letra en blanco eram cambiarias. En este sentido podemos decir que la efectividad cambiaria de las obligaciones contenidas en una letra en blanco depende de la existencia de una letra de cambio completa."

45 ARAÚJO, Danilo Borges dos Santos Gomes de. O formalismo dos títulos de crédito como segurança jurídica in GORGA, Érica; SICA, Lígia Paula Pinto. Estudos avançados de Direito Empresarial: títulos de crédito. Rio de Janeiro: Elsevier, 2013. p. 07.

46 SPADA, Paolo. Questioni in tema di cambiale in bianco in PELLIZZI, Giovanni. I titoli di credito. Milão: Giuffrè, 1980. p. 251.

${ }^{47}$ Ibidem. p. 250-251

${ }^{48}$ ADAMEK, Marcelo Vieira von. Títulos de crédito incompletos (títulos típicos e atípicos) in GORGA, Érica; SICA, Lígia Paula Pinto. Estudos avançados de Direito Empresarial: títulos de crédito. Rio de Janeiro: Elsevier, 2013. p. 205.

${ }^{49}$ Ibidem. p. 205-206; Tal requisito é expressamente exigido no art. 889 do CC: Art. 889. Deve o título de crédito conter a data da emissão, a indicação precisa dos direitos que confere, e a assinatura do emitente; Arnaldo Bruschettini assevera que o título deve ser assinado pelo devedor, o que constitui a expressão da vontade, mas que é possível substituir por um sinal convencional a estabelecer de modo seguro a identidade do devedor, como já ocorre com o bilhete ferroviário ou de navegação, como consta em BRUSCHETTINI, Arnaldo. Trattato dei titoli al portatore. Turim: Fratelli Bocca, 1898. p. 368.

${ }^{50}$ Lei 7.357/1985 - Art . 1응 O cheque contêm: [omissis] Parágrafo único A assinatura do emitente ou a de seu mandatário com poderes especiais pode ser constituída, na forma de legislação específica, por chancela mecânica ou processo equivalente.

${ }^{51}$ CC - Art. 889. Deve o título de crédito conter a data da emissão, a indicação precisa dos direitos que confere, e a assinatura do emitente. [omissis] § $3^{\circ} \mathrm{O}$ título poderá ser emitido a partir dos caracteres criados em computador ou meio técnico equivalente e que constem da escrituração do emitente, observados os requisitos mínimos previstos neste artigo.

52 ADAMEK, Marcelo Vieira von. Títulos de crédito incompletos (títulos típicos e atípicos) in GORGA, Érica; SICA, Lígia Paula Pinto. Estudos avançados de Direito Empresarial: títulos de crédito. Rio de Janeiro: Elsevier, 2013. p. 206. 
53 CC - Art. 903. Salvo disposição diversa em lei especial, regem-se os títulos de crédito pelo disposto neste Código.

54 ADAMEK, Marcelo Vieira von. Títulos de crédito incompletos (títulos típicos e atípicos) in GORGA, Érica; SICA, Lígia Paula Pinto. Estudos avançados de Direito Empresarial: títulos de crédito. Rio de Janeiro: Elsevier, 2013. p. 207.

55 ASQUINI, Alberto. Lezioni di Diritto Commerciale: titoli di credito e in particolare cambiale e titoli bancari di pagamento. Pádua: CEDAM, 1951. p. 201; BRUSCHETTINI, Arnaldo. Trattato dei titoli al portatore. Turim: Fratelli Bocca, 1898. p. 351.

56 ASQUINI, Alberto. Lezioni di Diritto Commerciale: titoli di credito e in particolare cambiale e titoli bancari di pagamento. Pádua: CEDAM, 1951. p. 201

57 Ibidem. p. 192; Anote-se que não há nulidade da obrigação constante no negócio jurídico subjacente por conta da ausência de uma assinatura válida lançada pelo devedor, mas pode se extrair do pretenso título um meio de prova, como consta em BRUSCHETTINI, Arnaldo. Trattato dei titoli al portatore. Turim: Fratelli Bocca, 1898. p. 370

58 ASQUINI, Alberto. Lezioni di Diritto Commerciale: titoli di credito e in particolare cambiale e titoli bancari di pagamento. Pádua: CEDAM, 1951. p. 192.

59 STJ, 3a Turma, REsp no ${ }^{\text {a }}$ 1.192.678/PR, Rel. Min. Paulo de Tarso Sanseverino, julgado em 13/11/2012.

${ }^{60}$ ASQUINI, Alberto. Lezioni di Diritto Commerciale: titoli di credito e in particolare cambiale e titoli bancari di pagamento. Pádua: CEDAM, 1951. p. 201.

61 ADAMEK, Marcelo Vieira von. Títulos de crédito incompletos (títulos típicos e atípicos) in GORGA, Érica; SICA, Lígia Paula Pinto. Estudos avançados de Direito Empresarial: títulos de crédito. Rio de Janeiro: Elsevier, 2013. p. 208; Alberto Asquini assinala que a autonomia da cambial deriva da aquisição de uma "cambial perfeita", não apenas de um documento que possa ser uma cambial, como consta em ASQUINI, Alberto. Lezioni di Diritto Commerciale: titoli di credito e in particolare cambiale e titoli bancari di pagamento. Pádua: CEDAM, 1951. p. 208 209. A mesma lição pode ser utilizada nos títulos de crédito atípicos.

62 ADAMEK, Marcelo Vieira von. Títulos de crédito incompletos (títulos típicos e atípicos) in GORGA, Érica; SICA, Lígia Paula Pinto. Estudos avançados de Direito Empresarial: títulos de crédito. Rio de Janeiro: Elsevier, 2013. p. 208; A cláusula cambiária é expressão do princípio da literalidade, característica universalmente admitida nos títulos de crédito, salvo raras exceções, e que é indispensável ao caráter autônomo (Bruschettini refere o caráter abstrato) da obrigação. Da literalidade é possível gerar a inoponibilidade ao terceiro de boa-fé, como consta em BRUSCHETTINI, Arnaldo. Trattato dei titoli al portatore. Turim: Fratelli Bocca, 1898. p. 371-374; No mesmo sentido, Marcelo Vieira von Adamek sustenta que o legislador privilegiou regras para prestigiar a circulação de títulos "incompletos", o que somente seria possível com a autonomia das obrigaçoes, como consta em ADAMEK, Marcelo Vieira von. Títulos de crédito incompletos (títulos típicos e atípicos) in GORGA, Érica; SICA, Lígia Paula Pinto. Estudos avançados de Direito Empresarial: títulos de crédito. Rio de Janeiro: Elsevier, 2013. p. 234

63 No caso do cheque não apenas constam os requisitos da Lei 7.357/1985 como possui modelo vinculado criado pela Resolução no 885/1983 do BACEN que uniformiza o formato do instrumento. No caso das duplicatas o modelo também é vinculado, conforme Resolução no $102 / 1968$ do BACEN, embora tal assertiva tenha sido profundamente abalada pela aproximação dos conceitos de boleto e de duplicata virtual no REsp no 1.024.691/PR (STJ, 3 ${ }^{\text {a }}$ Turma, Rel. Min. Nancy Andrighi, julgado em 22/03/2011); Sobre títulos de crédito vinculados, veja ASQUINI, Alberto. Lezioni di Diritto Commerciale: titoli di credito e in particolare cambiale e titoli bancari di pagamento. Pádua: CEDAM, 1951. p. 100.

${ }^{64} \mathrm{CC}$ - Art. 889. Deve o título de crédito conter a data da emissão, a indicação precisa dos direitos que confere, e a assinatura do emitente; O STJ se pronunciou em 2011 para afirmar que "Os títulos de crédito são numerus clausus no ordenamento jurídico, isto é, há necessidade de haver um dispositivo legal que diga que determinado documento se qualifica juridicamente como título de crédito. Mas, no caso, não foi apontado nenhum dispositivo legal em que se enquadrem os contratos, como títulos de crédito, nem se consegue imaginar onde, como títulos de crédito, ubicálos". Portanto, o Superior Tribunal de Justiça refutou a existência de títulos de crédito atípicos em trecho do corpo do acórdão (que não replica o pensamento na ementa), como consta em STJ, 3- Turma, REsp $\mathrm{n}^{\mathrm{a}}$ 1.190.899/SP, Rel. Min. Sidnei Beneti, julgado em 06/12/2011; Marcelo Vieira von Adamek sustenta que títulos de crédito atípicos estão legitimados em nosso ordenamento jurídico, como consta em ADAMEK, Marcelo Vieira von. Títulos de crédito incompletos (títulos típicos e atípicos) in GORGA, Érica; SICA, Lígia Paula Pinto. Estudos avançados de Direito Empresarial: títulos de crédito. Rio de Janeiro: Elsevier, 2013. p. 196.
65 Ibidem. p. 209

66 Ibidem. p. 210-211

67 ARAÚJO, Danilo Borges dos Santos Gomes de. O formalismo dos títulos de crédito como segurança jurídicain GORGA, Érica; SICA, Lígia Paula Pinto. Estudos avançados de Direito Empresarial: títulos de crédito. Rio de Janeiro: Elsevier, 2013. p. 16.

68 SPADA, Paolo. Questioni in tema di cambiale in bianco in PELLIZZI, Giovanni. I titoli di credito. Milão: Giuffrè, 1980. p. 251.

69 ASQUINI, Alberto. Lezioni di Diritto Commerciale: titoli di credito e in particolare cambiale e titoli bancari di pagamento. Pádua: CEDAM, 1951. p. 188.

${ }^{70}$ Que pode ser verbal ou escrito, bem como expresso ou tácito. Por seu caráter patrimonial, pode ser transmitido a terceiro, como consta em ADAMEK, Marcelo Vieira von. Títulos de crédito incompletos (títulos típicos e atípicos) in GORGA, Erica; SICA, Lígia Paula Pinto. Estudos avançados de Direito Empresarial: títulos de crédito. Rio de Janeiro: Elsevier, 2013. p. 217-218.

71 SPADA, Paolo. Questioni in tema di cambiale in bianco in PELLIZZI, Giovanni. I titoli di credito. Milão: Giuffrè, 1980. p. 253-256.

72 Marcelo Vieira von Adamek assinala que os Tribunais tem afastado o pacto de preenchimento em relações de consumo como forma de proteger o consumidor, embora ressalve sua contrariedade, porque o acordo não implica imposição, bem como não priva o signatário de defesa. Complementa para afirmar que proteção ao consumidor encarece o próprio crédito do consumidor, como consta em ADAMEK, Marcelo Vieira von. Títulos de crédito incompletos (títulos típicos e atípicos) in GORGA, Érica; SICA, Lígia Paula Pinto. Estudos avançados de Direito Empresarial: títulos de crédito. Rio de Janeiro: Elsevier, 2013. p. 222.

73 Isso porque a legislação permite a integração de um título não completo cotejando com a previsão legislativa para determinadas omissões, podendo ser completo "por integração", como consta em LERMA, Gemma Angélica Sánchez. La letra de cambio en blanco. Barcelona: Bosch, 1999. p. 256; O TJ-RS teve a oportunidade de analisar caso diverso do mencionado, em que nota promissória foi emitida em branco, com posterior preenchimento de moeda que não existia ao tempo da emissão (mas existia ao tempo do preenchimento), situação que invalidou o título de crédito (TJ-RS, 10aㅡ Câmara Cível, Apelação Cível nº 70006975718 , Rel. Des. Paulo Antônio Kretzmann, julgado em 11/12/2003).

74 LERMA, Gemma Angélica Sánchez. La letra de cambio en blanco. Barcelona: Bosch, 1999. p. 257.

75 O STJ já decidiu que mesmo em títulos abstratos pode ser essencial provar a sua causa, como ocorre na falência, em respeito ao interesse dos credores. STJ, $3^{\text {a }}$ Turma, REsp no ${ }^{\circ}$ 890.518/SC, Rel. Min. Nancy Andrighi, julgado em 20/10/2009.

76 ASCARELLI, Tullio. Teoria geral dos títulos de crédito. Campinas: Servanda, 2013. p. 66.

77 O STJ analisou caso em que o credor emitiu duplicata com base em compra e venda mercantil, a qual foi parcialmente paga pelo devedor. Entendeu a Corte Superior que estava legitimada a emissão de nova duplicata representativa do saldo, em razão da efetividade, como consta em STJ, 3- Turma, REsp no 302.028/MG, Rel. Min. Nancy Andrighi, julgado em 05/12/2002.

78 ASQUINI, Alberto. Lezioni di Diritto Commerciale: titoli di credito e in particolare cambiale e titoli bancari di pagamento. Pádua: CEDAM, 1951. p. 103.

79 Ibidem. p. 100

${ }^{80}$ ADAMEK, Marcelo Vieira von. Títulos de crédito incompletos (títulos típicos e atípicos) in GORGA, Érica; SICA, Lígia Paula Pinto. Estudos avançados de Direito Empresarial: títulos de crédito. Rio de Janeiro: Elsevier, 2013. p. 216; FARIA, Werter R. Cheque: as convenções de Genebra e o direito brasileiro. Porto Alegre, SAFE, 1978. p. 113.

81 Conforme Tullio Ascarelli é regra comum a todos os títulos de crédito a inoponibilidade de exceções perante terceiro de boa-fé que ignore os vícios da constituição do crédito (relação fundamental), como consta em ASCARELLI, Tullio. Teoria geral dos títulos de crédito. Campinas: Servanda, 2013. p. 249; ADAMEK, Marcelo Vieira von. Títulos de crédito incompletos (títulos típicos e atípicos) in GORGA, Érica; SICA, Lígia Paula Pinto. Estudos avançados de Direito Empresarial: títulos de crédito. Rio de Janeiro: Elsevier, 2013. p. 233-235.

82 ASQUINI, Alberto. Lezioni di Diritto Commerciale: titoli di credito e in particolare cambiale e titoli bancari di pagamento. Pádua: CEDAM 1951. p. 199-200 e 212; ASCARELLI, Tullio. Teoria geral dos títulos de crédito. Campinas: Servanda, 2013. p. 69.

83 Decreto no $57.663 / 1966$ - Art. 70 - Todas as ações contra ao aceitante relativas a letras prescrevem em três anos a contar do seu vencimento.

84 Decreto no ${ }^{2}$ 57.663/1966 - Art. 77 - São aplicáveis às notas promissórias, na parte em que não sejam contrárias a natureza deste título, as disposições relativas as letras e concernentes: [omissis] Prescrição (artigos 70 e 71) 
${ }^{85}$ Lei 5.474/1968 - Art 18 - A pretensão à execução da duplicata prescreve: 1 - contra o sacado e respectivos avalistas, em 3(três) anos, contados da data do vencimento do título;

${ }^{86}$ Lei n⿳ 7.357 - Art . $33 \mathrm{O}$ cheque deve ser apresentado para pagamento, a contar do dia da emissão, no prazo de 30 (trinta) dias, quando emitido no lugar onde houver de ser pago; e de 60 (sessenta) dias, quando emitido em outro lugar do País ou no exterior.

Art. 59 Prescrevem em 6 (seis) meses, contados da expiração do prazo de apresentação, a ação que o art. 47 desta Lei assegura ao portador.

87 ADAMEK, Marcelo Vieira von. Títulos de crédito incompletos (títulos típicos e atípicos) in GORGA, Érica; SICA, Lígia Paula Pinto. Estudos avançados de Direito Empresarial: títulos de crédito. Rio de Janeiro: Elsevier, 2013. p. 220.

${ }^{88}$ Ibidem. p. 221.

${ }^{89}$ Ibidem. p. 212.

${ }^{90}$ BRUSCHETTINI, Arnaldo. Trattato dei titoli al portatore. Turim: Fratelli Bocca, 1898. p. 365.

91 SPADA, Paolo. Questioni in tema di cambiale in bianco in PELLIZZI, Giovanni. I titoli di credito. Milão: Giuffrè, 1980. p. 262.

92 Gemma Angélica Sánchez Lerma distingue preenchimento abusivo, em que o acordo de preenchimento não é respeitado, do preenchimento arbitrário, em que inexiste pacto, como consta em LERMA, Gemma Angélica Sánchez. La letra de cambio en blanco. Barcelona: Bosch, 1999. p. 278.

${ }^{93}$ ADAMEK, Marcelo Vieira von. Títulos de crédito incompletos (títulos típicos e atípicos) in GORGA, Érica; SICA, Lígia Paula Pinto. Estudos avançados de Direito Empresarial: títulos de crédito. Rio de Janeiro: Elsevier, 2013. p. 238; No mesmo sentido, STJ, 4ㄹ Turma, REsp no 11.468/RS, Rel. Min. Sálvio de Figueiredo Teixeira, julgado em 07/04/1992 e STJ, 3를 Turma, REsp no 57.827/MG, Rel. Min. Costa Leite, julgado em 14/03/1995.

${ }^{94} \mathrm{CC}$ - Art. 889. Deve o título de crédito conter a data da emissão, a indicação precisa dos direitos que confere, e a assinatura do emitente.

${ }^{95}$ STJ, $3^{\text {a }}$ Turma, REsp no ${ }^{\text {8 }}$ 89.898/BA, Rel. Min. Nilson Naves, julgado em $10 / 12 / 1996$

${ }_{96}$ DOLINGER, Jacob. Direito Internacional Privado: parte geral. 10. ed. Rio de Janeiro: Forense, 2012. p. 327. Alerta que capacidade é aferida pelo art. $2^{\circ}$ da LUG como sendo a partir das regras de nacionalidade.

97 ASQUINI, Alberto. Lezioni di Diritto Commerciale: titoli di credito e in particolare cambiale e titoli bancari di pagamento. Pádua: CEDAM, 1951. p. 199-200; BRUSCHETTINI, Arnaldo. Trattato dei titoli al portatore. Turim: Fratelli Bocca, 1898. p. 365-366.

98 ADAMEK, Marcelo Vieira von. Títulos de crédito incompletos (títulos típicos e atípicos) in GORGA, Érica; SICA, Lígia Paula Pinto. Estudos avançados de Direito Empresarial: títulos de crédito. Rio de Janeiro: Elsevier, 2013. p. 213.

${ }^{99}$ STJ, 3ํㅡㄹ Turma, REsp n⿳0 612.423/DF, Rel. Min. Nancy Andrighi, julgado em $01 / 06 / 2006$

${ }^{100}$ STJ, 2aㅡ Seção, REsp nº 1.068.513/DF, Rel. Min. Nancy Andrighi, julgado em 14/09/2011.

${ }^{101}$ CC - Art. 889. Deve o título de crédito conter a data da emissão, a indicação precisa dos direitos que confere, e a assinatura do emitente. $\S 1^{\circ}$ É à vista o título de crédito que não contenha indicação de vencimento; Marcelo Vieira von Adamek aponta que a ausência de indicação de vencimento faz que seja considerado um título de crédito à vista, como consta em ADAMEK, Marcelo Vieira von. Títulos de crédito incompletos (títulos típicos e atípicos) in GORGA, Érica; SICA, Lígia Paula Pinto. Estudos avançados de Direito Empresarial: títulos de crédito. Rio de Janeiro: Elsevier, 2013. p. 214.

${ }^{102}$ ASQUINI, Alberto. Lezioni di Diritto Commerciale: titoli di credito e in particolare cambiale e titoli bancari di pagamento. Pádua: CEDAM, 1951. p. 193

${ }^{103}$ Danilo Borges dos Santos Gomes de Araújo adota esta posição e sustenta que não é essencial constar a data de emissão em títulos de crédito, como consta em ARAÚJO, Danilo Borges dos Santos Gomes de. O formalismo dos títulos de crédito como segurança jurídicain GORGA, Érica; SICA, Lígia Paula Pinto. Estudos avançados de Direito Empresarial: títulos de crédito. Rio de Janeiro: Elsevier, 2013. p. 12; Por razões similares sustentou esta posição Arnaldo Bruschettini, relacionando a possibilidade de se afastar a necessidade de data de emissão ou de vencimento de um título, como consta em BRUSCHETTINI, Arnaldo. Trattato dei titoli al portatore. Turim: Fratelli Bocca, 1898. p. 366-367.

${ }^{104}$ STJ, 3 a Turma, AgRg no REsp no $1.229 .253 /$ SP, Rel. Min. Paulo de Tarso Sanseverino, julgado em 21/02/2013.

${ }^{105}$ BRUSCHETTINI, Arnaldo. Trattato dei titoli al portatore. Turim: Fratelli Bocca, 1898. p. 346; Complementa o autor para afirmar que na incapacidade absoluta não há como não afirmar-se que o devedor poderá opor exceções ao terceiro de boa-fé, como consta à p. 349 .
${ }^{106}$ Ibidem. p. 347-348.

${ }^{107}$ ASQUINI, Alberto. Lezioni di Diritto Commerciale: titoli di credito e in particolare cambiale e titoli bancari di pagamento. Pádua: CEDAM, 1951. p. 212

${ }^{108}$ Concorda com esta posição ARAÚJO, Danilo Borges dos Santos Gomes de. O formalismo dos títulos de crédito como segurança jurídicain GORGA, Érica; SICA, Lígia Paula Pinto. Estudos avançados de Direito Empresarial: títulos de crédito. Rio de Janeiro: Elsevier, 2013. p. 13, assinalando que não se deve admitir nem mesmo a irregularidade da data, como a data de emissão erroneamente preenchida posteriormente à data de vencimento, à morte ou a interdição do emitente.

${ }^{109}$ STJ, 4a Turma, REsp n⿳o 162.336/SP, Rel. Min. Sálvio de Figueiredo Teixeira, julgado em 08/02/2000.

${ }^{110}$ BRUSCHETTINI, Arnaldo. Trattato dei titoli al portatore. Turim: Fratelli Bocca, 1898. p. 349-350.

${ }^{111}$ Decreto $\mathrm{n}^{\mathrm{o}} 57.663 / 1966$ - Art. 76. O título em que faltar algum dos requisitos indicados no artigo anterior não produzirá efeito como nota promissória, salvo nos casos determinados das alíneas seguintes.

A nota promissória em que não se indique a época do pagamento será considerada pagável à vista.

$\mathrm{Na}$ falta de indicação especial, lugar onde o título foi passado considera-se como sendo o lugar do pagamento e, ao mesmo tempo, o lugar do domicílio do subscritor da nota promissória.

A nota promissória que não contenha indicação do lugar onde foi passada considera-se como tendo-o sido no lugar designado ao lado do nome do subscritor.

${ }^{112}$ STJ, 4aㅡ Turma, REsp no 1.352.704/MG, Rel. Min. Luís Felipe Salomão, julgado em 11/02/2014; Alberto Asquini assinalou, utilizando-se do Direito italiano à época vigente, que a ausência de indicação do lugar de pagamento não invalida a cambial. A letra de câmbio é pagável no domicílio do sacado e a nota promissória no domicílio do emitente (ambas no domicílio do devedor), como consta em ASQUINI, Alberto. Lezioni di Diritto Commerciale: titoli di credito e in particolare cambiale e titoli bancari di pagamento. Pádua: CEDAM, 1951. p. 196; No mesmo sentido, BRUSCHETTINI, Arnaldo. Trattato dei titoli al portatore. Turim: Fratelli Bocca, 1898. p. 368; ARAÚJO, Danilo Borges dos Santos Gomes de. O formalismo dos títulos de crédito como segurança jurídicain GORGA, Érica; SICA, Lígia Paula Pinto. Estudos avançados de Direito Empresarial: títulos de crédito. Rio de Janeiro: Elsevier, 2013. p. 15.

${ }^{113}$ CC - Art. 889. Deve o título de crédito conter a data da emissão, a indicação precisa dos direitos que confere, e a assinatura do emitente. § $2^{\text {o }}$ Considera-se lugar de emissão e de pagamento, quando não indicado no título, o domicílio do emitente.

${ }^{114}$ ASQUINI, Alberto. Lezioni di Diritto Commerciale: titoli di credito e in particolare cambiale e titoli bancari di pagamento. Pádua: CEDAM, 1951. p. 200; BASSO, Maristela. Curso de Direito Internacional Privado. 2. ed. São Paulo: Atlas, 2011. p. 190; Igualmente, consta no Código Bustamante, do qual o Brasil é signatário: "Art. 264. Na falta de convênio expresso ou tácito, as relações jurídicas entre o sacador e o tomador serão reguladas pela lei do lugar em que a letra se saca".

${ }^{115} \mathrm{CC}-$ Art. 71. Se, porém, a pessoa natural tiver diversas residências, onde, alternadamente, viva, considerar-se-á domicílio seu qualquer delas.

${ }^{116}$ LÔBO, Paulo. Direito Civil: parte geral. 3. ed. São Paulo: Saraiva, 2012. p. 124; AZEVEDO, Álvaro Villaça. Teoria Geral do Direito Civil. São Paulo: Atlas, 2012. p. 123

${ }^{117}$ LÔBO, Paulo. Direito Civil: parte geral. 3. ed. São Paulo: Saraiva, 2012. p. 188.

${ }^{118}$ Marcelo Vieira von Adamek assim retrata a posição da maioria, como consta em ADAMEK, Marcelo Vieira von. Títulos de crédito incompletos (títulos típicos e atípicos) in GORGA, Érica; SICA, Lígia Paula Pinto. Estudos avançados de Direito Empresarial: títulos de crédito. Rio de Janeiro: Elsevier, 2013. p. 224-226; Esta é a posição sustentada em ARAÚJO, Danilo Borges dos Santos Gomes de. O formalismo dos títulos de crédito como segurança jurídicain GORGA, Érica; SICA, Lígia Paula Pinto. Estudos avançados de Direito Empresarial: títulos de crédito. Rio de Janeiro: Elsevier, 2013. p. 15; No mesmo sentido, ASQUINI, Alberto. Lezioni di Diritto Commerciale: titoli di credito e in particolare cambiale e titoli bancari di pagamento. Pádua: CEDAM, 1951. p. 206.

${ }^{119}$ Marcelo Vieira von Adamek assim retrata a posição da maioria, como consta em ADAMEK, Marcelo Vieira von. Títulos de crédito incompletos (títulos típicos e atípicos) in GORGA, Érica; SICA, Lígia Paula Pinto. Estudos avançados de Direito Empresarial: títulos de crédito. Rio de Janeiro: Elsevier, 2013. p. 226.

${ }^{120}$ STJ, 4 ${ }^{\text {a }}$ Turma, REsp no ${ }^{8}$ 870.704/SC, Rel. Min. Luís Felipe Salomão, julgado em 14/06/2011; STJ, 3ª Turma, REsp no 1.017.970/DF, Rel. Min. Nancy Andrighi, julgado em 26/08/2008; STJ, 3 a Turma, REsp no 264.174/PR, Rel. Min. Carlos Alberto Menezes Direito, julgado em 13/12/2001; No mesmo sentido segue a Súmula no 387 do STF: A cambial 
emitida ou aceita com omissões, ou em branco, pode ser completada pelo credor de boa-fé antes da cobrança ou do protesto; Igualmente, TJ-RS, 18ª Câmara Cível, Apelação Cível nº 70052217866, Rel. Des. Nelson José Gonzaga, julgado em 28/03/2013 e TJ-RS, 9ª Câmara Cível, Apelação Cível nº 70027586833, Rel. Des. Odone Sanguiné, julgado em $18 / 02 / 2009$.

${ }^{121}$ STF, Tribunal Pleno, RE nº 42.945/SP, Rel. Min. Gonçalves de Oliveira, julgado em 15/05/1961

${ }^{122}$ Art. 54. A nota promissória é uma promessa de pagamento e deve conter estes requisitos essenciais, lançados, por extenso no contexto: § 4을 Não será nota promissória o escrito ao qual faltar qualquer dos requisitos acima enumerados. Os requisitos essenciais são considerados lançados ao tempo da emissão da nota promissória. No caso de má-fé do portador, será admitida prova em contrário.

${ }^{123}$ STF, $1^{\text {a }}$ Turma, AI no 22.875 , Rel. Min. Nelson Hungria, julgado em $11 / 08 / 1960$

${ }^{124}$ Decreto no $57.663 / 1966$ - Art. 10 - Se uma letra incompleta no momento de ser passada tiver sido completada contrariamente aos acordos realizados não pode a inobservância desses acordos ser motivo de oposição ao portador, salvo se este tiver adquirido a letra de má-fé ou, adquirindo-a, tenha cometido uma falta grave.

Art. 77 - São aplicáveis às notas promissórias, na parte em que não sejam contrárias a natureza deste título, as disposições relativas as letras e concernentes: [omissis] São igualmente aplicáveis às notas promissórias as disposições relativas as letras pagáveis no domicílio de terceiros ou numa localidade diversa da do domicílio do sacado (artigos 4 e 27), a estipulação de juros (artigo 5), as divergências das indicações da quantia a pagar (artigo 6), as conseqüências da aposição de uma assinatura nas condições indicadas no artigo 7 , as da assinatura de uma pessoa que age sem poderes ou excedendo os seus poderes (artigo 8) e a letra em branco (artigo 10).

${ }^{125}$ LERMA, Gemma Angélica Sánchez. La letra de cambio en blanco. Barcelona: Bosch, 1999. p. 252-254.

${ }^{126}$ ADAMEK, Marcelo Vieira von. Títulos de crédito incompletos (títulos típicos e atípicos) in GORGA, Érica; SICA, Lígia Paula Pinto. Estudos avançados de Direito Empresarial: títulos de crédito. Rio de Janeiro: Elsevier, 2013. p. 219.

${ }^{127}$ Ibidem. p. 227.

${ }^{128}$ Ibidem. p. 227; LERMA, Gemma Angélica Sánchez. La letra de cambio en blanco. Barcelona: Bosch, 1999. p. 271-273; Gemma Angélica Sánchez Lerma refere que em sentença de Madri de 1995 juiz declarou que fica privado de força executiva o título porque o preenchimento abusivo retirou certeza e liquidez da dívida, constituindo-se uma posição minoritária, como consta na p. 272

${ }^{129}$ Marcelo Vieira von Adamek sustenta que é possível ao devedor ingressar em juízo promovendo pedido cautelar contra o devedor de má-fé para impedir a circulação do título, não permitindo que seja gerada a posição do portador de boa-fé, como consta em ADAMEK, Marcelo Vieira von. Títulos de crédito incompletos (títulos típicos e atípicos) in GORGA, Érica; SICA, Lígia Paula Pinto. Estudos avançados de Direito Empresarial: títulos de crédito. Rio de Janeiro: Elsevier, 2013. p. 240.

${ }^{130}$ Ibidem. p. 228; LERMA, Gemma Angélica Sánchez. La letra de cambio en blanco. Barcelona: Bosch, 1999. p. 260 e 273.

${ }^{131}$ Ibidem. p. 260

${ }^{132}$ Observando-se que apesar da confusão jurisprudencial e doutrinária reinante, não é sinônimo de abstração.

${ }^{133}$ Entende-se por relação mediata aquela que não é direta entre devedor e credor. Por exemplo, na emissão de nota promissória, o emitente $\mathrm{X}$ emite o título destinando como credor o beneficiário Y. Posteriormente, $\mathrm{Y}$ endossa o título para $\mathrm{Z}$. Existe relação imediata (direta) entre $\mathrm{X}$ e Y, bem como entre $\mathrm{Y}$ e $\mathrm{Z}$, mas a relação é mediata entre $\mathrm{X}$ e $\mathrm{Z}$.

${ }^{134}$ ADAMEK, Marcelo Vieira von. Títulos de crédito incompletos (títulos típicos e atípicos) in GORGA, Érica; SICA, Lígia Paula Pinto. Estudos avançados de Direito Empresarial: títulos de crédito. Rio de Janeiro: Elsevier, 2013. p. 229; ASQUINI, Alberto. Lezioni di Diritto Commerciale: titoli di credito e in particolare cambiale e titoli bancari di pagamento. Pádua: CEDAM, 1951. p. 211; No mesmo sentido indica Gemma Angélica Sánchez Lerma que apenas destaca que inoponibilidade de exceção de preenchimento indevido contra o terceiro de boa-fé não se compara com a exceção de falsificação que é oponível inclusive aos terceiros de boa-fé, como consta em LERMA, Gemma Angélica Sánchez. La letra de cambio en blanco. Barcelona: Bosch, 1999. p. 261-263.
${ }^{135}$ LERMA, Gemma Angélica Sánchez. La letra de cambio en blanco. Barcelona: Bosch, 1999. p. 264.

${ }^{136}$ Decreto no 57.663/1966 - Art. 10 - Se uma letra incompleta no momento de ser passada tiver sido completada contrariamente aos acordos realizados não pode a inobservância desses acordos ser motivo de oposição ao portador, salvo se este tiver adquirido a letra de máfé ou, adquirindo-a, tenha cometido uma falta grave; Marcelo Vieira von Adamek menciona que as expressões má-fé e culpa grave não são sinônimas, como consta em ADAMEK, Marcelo Vieira von. Títulos de crédito incompletos (títulos típicos e atípicos) in GORGA, Érica; SICA, Lígia Paula Pinto. Estudos avançados de Direito Empresarial: títulos de crédito. Rio de Janeiro: Elsevier, 2013. p. 231.

${ }^{137} \mathrm{CC}$ - Art. 903. Salvo disposição diversa em lei especial, regem-se os títulos de crédito pelo disposto neste Código.

${ }^{138} \mathrm{CC}$ - Art. 891. O título de crédito, incompleto ao tempo da emissão, deve ser preenchido de conformidade com os ajustes realizados. Parágrafo único. O descumprimento dos ajustes previstos neste artigo pelos que deles participaram, não constitui motivo de oposição ao terceiro portador, salvo se este, ao adquirir o título, tiver agido de má-fé; No mesmo sentido, ADAMEK, Marcelo Vieira von. Títulos de crédito incompletos (títulos típicos e atípicos) in GORGA, Érica; SICA, Lígia Paula Pinto. Estudos avançados de Direito Empresarial: títulos de crédito. Rio de Janeiro: Elsevier, 2013. p. 230.

${ }^{139}$ ASQUINI, Alberto. Lezioni di Diritto Commerciale: titoli di credito e in particolare cambiale e titoli bancari di pagamento. Pádua: CEDAM, 1951. p. 211; Gemma Angélica Sánchez Lerma menciona que há autores como Eizaguirre que sustentam que desconhecimento de termos de pacto por negligência ou culpa já constitui má-fé, como consta em LERMA Gemma Angélica Sánchez. La letra de cambio en blanco. Barcelona: Bosch, 1999. p. 268

${ }^{140}$ Decreto no $1669-1933$ - Art.14. Se una cambiale, incompleta quando fu emessa, venga completata contrariamente agli accordi interceduti, la inosservanza di tali accordi non può essere opposta al portatore, a meno che questi abbia acquistato la cambiale in mala fede, ovvero abbia commesso colpa grave acquistandola.

Il portatore decade dal diritto di riempire la cambiale in bianco dopo tre anni dal giorno dell'emissione del titolo.

Tale decadenza non è opponibile al portatore di buona fede, al quale il titolo sia pervenuto già completo.

${ }^{141}$ ADAMEK, Marcelo Vieira von. Títulos de crédito incompletos (títulos típicos e atípicos) in GORGA, Érica; SICA, Lígia Paula Pinto. Estudos avançados de Direito Empresarial: títulos de crédito. Rio de Janeiro: Elsevier, 2013. p. 229.

${ }^{142}$ LERMA, Gemma Angélica Sánchez. La letra de cambio en blanco. Barcelona: Bosch, 1999. p. 266-269; Em sentido similar consta no art. $6^{\circ}$ da Convenção das Nações Unidas sobre Letra de Câmbio Internacional, exigindo-se que o portador tenha conhecimento mais apurado sobre a existência e o conteúdo do pacto de preenchimento nos casos em que o portador recebe um título ainda não completo.

${ }^{143}$ ADAMEK, Marcelo Vieira von. Títulos de crédito incompletos (títulos típicos e atípicos) in GORGA, Érica; SICA, Lígia Paula Pinto. Estudos avançados de Direito Empresarial: títulos de crédito. Rio de Janeiro: Elsevier, 2013. p. 232; LERMA, Gemma Angélica Sánchez. La letra de cambio en blanco. Barcelona: Bosch, 1999. p. 269; Gemma Angélica Sánchez Lerma refere que se o adquirente anterior ao portador estava de boa-fé, o portador (ou os posteriores em caso de novo endosso) também serão rotuláveis como de boa-fé, como consta na p. 271. No entanto, parece ser uma presunção razoável que admitiria prova em contrário, na medida em que o atual portador poderia conhecer das exceções por pessoa diversa daquelas que participaram da relação cambiária.

${ }^{144}$ LERMA, Gemma Angélica Sánchez. La letra de cambio en blanco. Barcelona: Bosch, 1999. p. 270.

${ }^{145}$ ADAMEK, Marcelo Vieira von. Títulos de crédito incompletos (títulos típicos e atípicos) in GORGA, Érica; SICA, Lígia Paula Pinto. Estudos avançados de Direito Empresarial: títulos de crédito. Rio de Janeiro: Elsevier, 2013. p. 236.

${ }^{146}$ LERMA, Gemma Angélica Sánchez. La letra de cambio en blanco. Barcelona: Bosch, 1999. p. 264-266.

${ }^{147}$ SPADA, Paolo. Questioni in tema di cambiale in bianco in PELLIZZI, Giovanni. I titoli di credito. Milão: Giuffrè, 1980. p. 256-257.

${ }^{148}$ LERMA, Gemma Angélica Sánchez. La letra de cambio en blanco. Barcelona: Bosch, 1999. p. 255. 